\title{
Changing semantic factors in case selection: Russian evidence from the last two century
}

\author{
Alexander Krasovitsky, Matthew Baerman, Dunstan Brown, Greville. G. Corbett \\ University of Surrey, UK
}

(draft of 09 May 2008)

\begin{abstract}
We present a corpus-based study of variation in case assignment of the direct object of negated verbs in Russian over the past 200 years. Superficially the system of case forms available over this relatively short period has remained largely the same, but the way in which certain cases are used has been radically altered. This is particularly apparent in the treatment of the direct object of negated verbs. We argue that various semantic factors have been involved in bringing about this change, and that the role and significance of these factors has been changing over the period under investigation. This has implications for our understanding of the role of semantics in case assignment.
\end{abstract}

\section{Genitive/accusative variation in Russian}

In modern Russian we observe variation in the case used to mark the direct object of a negated verb, either accusative (1a) or genitive (1b).
(1a)
$O$ ne kupil žurnal
he not bought magazine[SG.ACC]
'He didn't buy a/the magazine.'
(1b) On ne kupil žurnal-a
he not bought magazine-SG.GEN
'He didn't buy a/the magazine.'

The corresponding sentence without negation, as in (2), requires the accusative for the direct object, with no other choice possible:

\section{(2) O kupil žurnal \\ he bought magazine[SG.ACC] \\ 'He bought a/the magazine.'}

In earlier periods, the distribution of the two cases with direct objects was clear-cut: the genitive marked the object of negated verbs, while the accusative marked the object of non-negated verbs. In other words, only constructions such as (2) and (1b) were allowed, while (1a) was ungrammatical. This started to change in the late seventeenth - early eighteenth centuries, when isolated instances of accusative objects governed by transitive verbs under negation appeared (Taubenberg 1958: 6; Borkovskij 1978: 327), though it was not until the early $19^{\text {th }}$ century that a noticeable number of examples started to appear (Bulaxovskij 1954: 349-350). Even then the expansion of the accusative was rather slow. As our data from the early $19^{\text {th }}$ century indicate (Figure 1), at that time only $11 \%$ of the constructions with a negated transitive verb had their direct object in the accusative case, while in the second half of the $19^{\text {th }}$ century the frequency of the accusative in such constructions is only slightly higher $(14 \%)$. In contrast, by the end of the $20^{\text {th }}$ century the split between accusative and genitive use 
was more or less equal: $49 \%$ of the constructions with a negated transitive verb have their direct object in the accusative case.

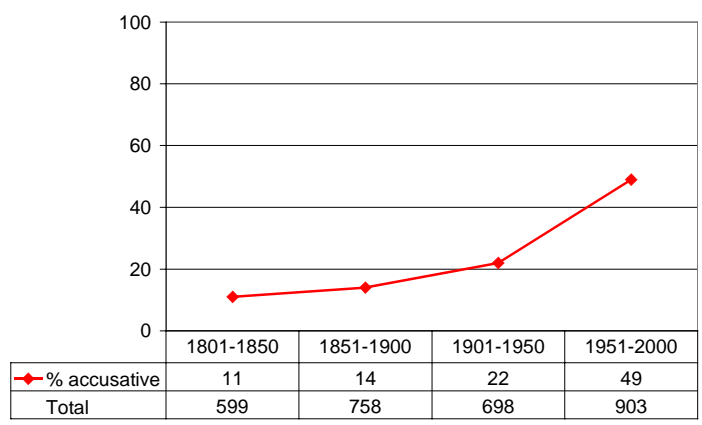

Figure 1. Change over time in frequency of accusative for the direct object of a negated verb ${ }^{1}$

In contemporary Russian we find three different types of construction with a negated transitive verb: one in which the genitive is still obligatory, as in (3), one in which it is optional, as in (4), and one in which it is ungrammatical (5).

(3a) On ne imee mašin-y i dač- $i$

he not have car-SG.GEN and cottage-SG.GEN

'He does not have a car and a country cottage.'

(3b)

*On ne imee mašin-u $i \quad$ dač-u

he not have car-SG.ACC and cottage-SG.ACC

'He does not have a car and a country cottage.'

$\begin{array}{llll}\text { On ne } & \text { kupil } & \text { bilet-ov } \\ \text { he } & \text { not } & \text { buy.PST } & \text { ticket-PL.GEN }\end{array}$

'He did not buy tickets.'

$\begin{array}{llll}\text { On ne } & \text { kupil } & \text { bilet-y } \\ \text { he } & \text { not } & \text { buy.PST } & \text { ticket-PL.ACC }\end{array}$

'He did not buy tickets.'

On svo-ju nevest-u

he his-SG.ACC fiancée-SG.ACC

nikogda ne provožaet

'He never sees his fiancée home.'

$\begin{array}{lllll}* O & \text { svo-ej nevest-y } & \text { nikogda } & \text { ne } & \text { provožaet } \\ n & & & \\ \text { he his-SG.GEN fiancée-SG.GEN } & \text { never } & \text { not } & \text { sees.home } \\ \text { 'He never sees his fiancée home.' } & & & \end{array}$

1 The research is based on the corpus compiled by Adrian Barentsen (University of Amsterdam). Sub-corpora sizes used for this study are as follows (in number of words with respect to periods): 1801-1850 - 684549, 1851-1900 - 431325, $1901-1950-419775,1951-2000-997352$. 
A variety of factors account for the direct object case in this construction. Thus in (3) the use of the genitive (the older type of case assignment) is still strongly favoured in the modern language with particular lexico-semantic classes of verbs, for example with verbs of possession. On the contrary, with animate objects, as in (5), the genitive has been almost completely ousted by the innovative accusative forms. However the majority of direct objects governed by negated verbs may take both cases, as in (4), and the choices are subject to a variety of conditioning factors.

\section{Research background: between obligatory distribution and optionality}

In contemporary Russian the choice between the two cases is determined by multiple factors, which either work in the same direction or conflict with each other (Restan (1960), Safarewiczowa (1960), Timberlake (1986), Mustajoki \& Heino (1991), Bailyn (1997), Padučeva (2006)). The question arises as to what extent each of the alternative case forms can be predicted on the basis of these factors.

A restrictive approach, making use of a single factor, is taken by Bailyn (1997), working from a generative perspective. Bailyn argues that the difference between accusative and genitive objects reflects a difference in syntactic structure: negated arguments in the genitive fall within existential closure, accounting for their "non-individuated", or existential reading, while accusative objects have "individuated, topical, or definite interpretation" and occupy a higher position in the syntactic tree. Thus, (6a) refers to the behaviour of the subject ( $S a \check{s} a)$ in general and has an existential reading (the object knig is generic), while (6b) decribes an actual process in which a particular object (knigi) is involved. This difference is reflected in the English translation: Sasha doesn't buy (any) books (never, existential reading) in (6a) and Sasha isn't buying books (now, individuated, definite reading) in (6b).
(6a) $S a \check{a} a$
ne pokupaet knig.
Saša not buys book[PL.GEN]
'Sasha doesn't buy (any) books.'
(6b) Saša ne pokupaet knig-i.
Saša not buys book-PL.ACC
'Sasha isn't buying books.'

However, this clear-cut distribution of case forms does not necessarily hold in contemporary Russian. Though Bailyn's analysis appears to capture the restrictions on the genitive, the range of the accusative is in fact broader, in some instances overlapping with the genitive. According to Bailyn, (6b) can have only one interpretation ("individuated, topical, or definite"), which is reflected in the translation: Sasha isn't buying books. (A situation that would make for such an interpretation could be in a bookshop, where Sasha is buying something, such as postcards, but not books.) At the same time it has been shown in other studies that the accusative objects of negated verbs may be understood non-referentially (for example, that Sasha is not in the habit of buying books), in which case (6b) gets an existential reading. Thus, a VP with the genitive has a single reading, while a VP with accusative objects may have two different readings. Consider examples from our corpus (1951-2000 time period):

Referential accusative object:

(7) Xejfec daže ne opublikoval svo-ju rabot-u, a ego... posadili. Xejfec even not published his-ACC work-ACC but him (they) imprisoned 'Xejfec did not even publish his work, but he was put in gaol all the same.' (Dovlatov) 
(8) Rozalinda pytaetsja skryt'sja ot presledovatelej tak, Rozalinda tries hide.herself.INF from persecutors so

čtoby oni ne našli naš-i sled-y.

in.order they not found our.ACC.PL tracks-ACC.PL

'Rozalinda tries to hide from her persecutors, so that they could not find our tracks.' (Strugackie)

Non-referential accusative object:

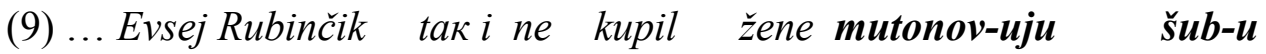

... Evsej Rubinčik just not bought wife mouton-ACC.SG fur.coat-ACC.SG

'...Evsej Rubinchik just did not buy a mouton fur coat for his wife.' (Dovlatov)

(10) Ja lično ne p’ju punš.

I personally not drink punch.ACC.SG

'I personally do not drink punch.' (Petruševskaja)

Non-referential genitive object:

(11)...gangstery ne vorujut čas-ov, daže tak-ix statrinn-yx i massivn-yx

...gangsters not steal clock-GEN.PL even such-GEN.PL ancient-GEN.PL and massive-GEN.PL

'...gangsters don't steal clocks, even such ancient and massive ones.' (Strugackie)

(12) My ne byli kar'eristami, ne pokupali avtomašin, ne važničali.

we not were careerists not bought cars.GEN.PL not put.on.airs

'We were not careerists; we didn't buy cars or put on airs.' (Dovlatov)

Babby (1980) recognizes that the accusative may overlap with the genitive in contexts which have a generic reading ('existential' in Bailyn's terms), and suggests an analysis based on two factors: the scope of negation and the referential status of the object. Babby argues that in order for the object to be in the genitive, both the verb and the object should be within the scope of negation; direct objects outside the scope of negation will have accusative case assignment. Thus, in (13a) both the verb and the object are negated, which is reflected by the genitive case on the object. (The test for the scope of negation would be the corresponding affirmative sentence: if the object is asserted in such a sentence along with the verb, i.e. if it is not topicalized and included in the comment (rheme), then it will be in the scope of negation.) The accusative however is much less restricted: it may appear both within and outside the scope of negation. Thus, in (13b) the accusative gives no indication of whether the object is in or outside the scope of negation. To prove that the object is not in the scope of negation (i. e. only the verb is negated), it is necessary to show that the sentence has a contrastive reading and that the object is topicalized (for example as in the following dialogue: Does he eat meat? - No, he does not eat meat, he only likes to cook it; the existence of meat is not denied, only the verbs are contrasted). As (13b) does not have a contrastive interpretation under normal sentence stress and intonation, there is no semantic evidence for claiming that the object in this sentence is not in the scope of negation (Babby 1980: 156). 
(13a) Brat ne est mjas-a.

brother not eats meat-GEN

'(My) brother doesn't eat meat.'

(13b) Brat ne est mjas-o.

brother not eats meat-ACC

'(My) brother doesn't eat meat.'

Therefore, the genitive case appears only in the scope of negation. However on its own, this condition is insufficient. Babby suggests further that when the object occurs in the scope of negation, then the choice between the genitive and accusative depends on the referential status of the object. Only indefinite objects may be in the genitive, while definite objects will be in the accusative. Outside the scope of negation the genitive may not occur, and objects will be in the accusative irrespective of definiteness/indefiniteness (Babby 1980: 157-158). On this interpretation, case is predictable if two factors, the scope of negation and referential status, are taken into account.

Padučeva (2006) argues however that even consideration of referential status may not fully account for case assignment, and in any event examples like (13b) are ambiguous in contemporary Russian. She considers two famous examples $(14 \mathrm{a}, \mathrm{b})$ from Tomson (1903), which are similar to (13a,b), and points out that while in (14a) the genitive object may be interpreted only as non-referential ( $v$ rodovom smysle), the accusative object in (14b) may be understood referentially ( $v$ konkretno-referentnom smysle), i.e. as this particular piece of food related to this particular action. But equally the accusative may have a non-referential reading similar to the genitive in (14a). Hence there is an overlap where the genitive and accusative co-occur, as the accusative allows two different readings.

(14a) Koška ne est vetčin-y.

cat not eats ham-GEN

'A/the cat doesn't eat ham.'

(14b) Koška ne est vetčin-u.

cat not eats ham-ACC

'A/the cat doesn't eat ham.'

This overlap, as Padučeva claims further, is a very recent innovation and is attested only with some speakers. In fact, in contemporary Russian there is no single unified semantic rule which would account for this variation. Instead, she proposes that there are three coexisting semantic rules, each reflecting a particular diachronic stage in the genitive-accusative shift, and speakers may have different preferences with respect to these rules. According to the first rule (which Padučeva assumes is the default), case assignment is linked to referential properties of the object in a straightforward way: referential noun phrases take the accusative and non-referential ones take the genitive. The second rule is an archaic one, according to which the genitive is used as a default case irrespective of the object noun phrase's referential properties, and the accusative is reserved only for referential objects ${ }^{1}$. The third rule is an innovation, and is the mirror-image of the archaic one. As discussed above with respect to (8a) and $8(\mathrm{~b})$, according to this rule the accusative is a default case and marks objects irrespective of their referential status, while the genitive is restricted to non-referential objects.

${ }^{1}$ It is noteworthy that Švedova's grammar (Russkaja Grammatika) of 1980 uses this rule in its own accounts of the distribution of the two cases in contemporary Russian (Švedova 1980: §2671). 
Padučeva's treatment is generally in accord with a number of analyses that indicate the use of the accusative in contemporary Russian has been increasing (Safarewiczowa 1960, Restan 1960). Given that the rate of change has been increasing over the last several decades (see Figure 1), the coexistence of several semantic rules that currently account for case assignment but are historically related to different periods and different language states is not surprising. It may be a difficult task, however, to pin these rules down on the basis of synchronic usage, as fluctuation and inconsistency is usually observed where an ongoing change is involved. To tease apart the different factors influencing case assignment we apply our analysis to data from several successive time periods and investigate them in detail using exhaustive corpus data. Approaching genitive/accusative variation from a diachronic perspective we show below that there is a relationship between the spread of the innovation in question and the continual change both in the number of conditioning factors, and in the role each factor has to play. We investigate the impact and interaction of three types of factors conditioning case assignment: verb-related, object-related and clause-related. The central point of the discussion is the relationship of verb aspect and referential properties of the object at different stages of the morphosyntactic change in question, and the interaction of semantic factors with structural conditions, such as the position of negation (direct vs. indirect) and the type of governing verb (finite vs. infinitive). We base our analysis on statistics derived from literary texts written between 1801 and 2000 . These are divided into four 50year periods, and presented separately for each of the conditioning factors under investigation.

\section{Verb aspect}

The relationship between direct object case assignment and the aspectual properties of the governing verb is well known and has been attested in a number of Slavic and non-Slavic languages. A famous example is Finnish, in which some transitive verbs allow variation in the case of direct objects, which are either accusative or partitive. Aspect in Finnish is not marked formally, so phrases get a particular aspectual reading from the case of the direct object: phrases with the accusative get a perfective reading and those with the partitive an imperfective reading (Comrie 1976: 8). Kiparsky (1998) argues that the partitive in Finnish is associated with aspectual unboundedness on the VP level, while the accusative indicates aspectually resultative, bounded events.

On the other hand, in languages with formally marked aspectual distinctions, the aspect of a transitive verb may trigger a particular case on direct objects. One such language is Old High German: perfectives took both accusative and genitive objects, while imperfectives could only govern objects marked for accusative (Abraham 1997). Abraham, following Leiss (1992) argues further for the strong correlation between verb aspect and case in OHG. Weakening of aspectual distinctions in late $\mathrm{OHG}$, according to this view, caused the decay of the verbally governed genitive in later periods (in Middle High German): the genitive was no longer used to mark objects of perfective verbs once the formally marked aspectual distinction disappeared ${ }^{2}$.

In Russian, a number of studies have shown that the case of a direct object is sensitive to the aspect of the governing verb in negated VPs (see, for example, Safarewiczowa (1960), Restan (1960), Mustajoki \& Heino (1991); for an alternative view see Dončeva (1962: 31)). Generally speaking, objects of negated transitive verbs are more likely to appear in the accusative if the governing verb is perfective (15a), while the frequency of genitive objects increases if the governing verb is imperfective (15b).

\footnotetext{
${ }^{2}$ Abraham refers to the dichotomy of simple (durative) verbs and verbs with perfectivizing verbal prefixes and prepositions in OHG. Apart from prefixed verbs, there were also "inherently perfective verbs". With both groups of perfective predicates genitive objects co-occurred "with more than arbitrary frequency" (Abraham 1997: 35).
} 
(15a) Ja ne pro-čita-l gazet-y.

I not PFV-read-PST paper-PL.ACC

'I did not read papers.'

$\begin{array}{cll}\text { (15b) } J a \text { ne čital } & \text { gazet. } \\ \text { I not }[\text { IPFV]read-PST } & \text { paper[PL.GEN] } \\ \text { 'I did not read papers.' } & \end{array}$

An explanation for this is suggested by Timberlake (1986), who analyzes this phenomenon according to the relationship between aspect and the scope of negation. In constructions with imperfective verbs the scope of negation covers the verb and the object ("the whole event, including the object participant", Timberlake 1986: 348); with perfective verbs the scope of negation is "the end point of the action, not the whole event". Accordingly, objects of negated perfective verbs are more likely to take the accusative, just as in affirmative constructions, showing that negation does not affect them. ${ }^{3}$

This sensitivity to aspectual semantics emerged at the early stage of the genitive-accusative shift and increased as use of the accusative spread. Data from our corpus show that in the early $19^{\text {th }}$ century, perfective verbs already had a slightly stronger preference for accusative objects than imperfectives ( 9 percent and 4 percent respectively) ${ }^{4}$. In the second half of the $19^{\text {th }}$ century the sensitivity of case assignment to aspectual semantics became more pronounced, and increased still further in the $20^{\text {th }}$ century (Figure 2$)^{5}$. However, if we look separately at perfective and imperfective verbs, we find two radically different scenarios across this two hundred year period. Until the middle of the $20^{\text {th }}$ century aspectual distinctions had an overwhelming effect on the shape of change: the accusative spread with perfective verbs, while imperfectives had very little tolerance for the innovation, and retained the genitive more than $90 \%$ of the time. Data from the $19^{\text {th }}$ and first half of the $20^{\text {th }}$ century indicate that there was a strong correlation between verb aspect and direct object case: perfectives triggered the accusative, imperfectives gave the genitive, as in (16) and (17).

(16) Esli davali emu pervyj tom, on po pročtenii ne prosi-l vtor-ogo...

if gave him first volume he after reading not [IPFV]ask-PST second-ACC.SG

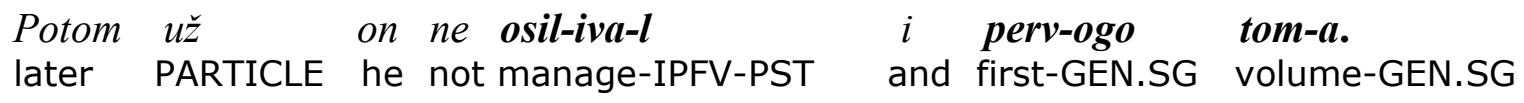

'If he was given the first volume, on reading it he never asked for the second... Later on he could never get through the first one.' (Gončarov)
Как ni
gorjačis'
èto ne vy-suš-it
naš-i
plat' $^{\prime}$-ja...
how PARTICLE get.angry this not PFV-dry-FUT
our-ACC.PL
clothes-ACC.PL

'However angry you get, this will not dry our clothes...' (Bestužev)

In the second half of the $20^{\text {th }}$ century the situation changed dramatically. The frequency of the accusative rose, with both aspects showing a similar rate of change (use of the accusative increased

\footnotetext{
${ }^{3}$ For an alternative view see Partee \& Borschev (2002), Padučeva (2006).

${ }^{4}$ Note that percentages given in Figure 2 are for objects of finite verbs only. Since infinitival constructions show different frequencies for genitive/accusative object case assignment (see section 4), the two types of governors, finite verbs and infinitives, should be considered separately.

${ }^{5}$ Thus, Tomson (1903) indicated the relevance of aspectual distinctions for the genitive/accusative variation in the language of his time.
} 
$22 \%$ with imperfective verbs and 26\% with perfectives from the period 1901-1950 to 1951-2000). From a diachronic perspective, it is obvious that aspect was no longer a crucial factor shaping the change. Until the middle of the $20^{\text {th }}$ century it severely constrained the spread of the accusative, restricting it to the objects of perfective verbs. In late twentieth century Russian, the imperfectivity of the governing verb stopped being a "disfavouring context" (Kroch 1989) for the accusative. This is contrary to what might be assumed on the basis of synchronic analysis, which points to the increasing gap between objects of perfective and imperfective verbs in terms of their preferences for case; from a historical perspective it is clear that the accusative in the second half of the $20^{\text {th }}$ century was spreading actively with both aspects. The fact that the imperfectives appear to lag behind is a consequence of the previous state of the language. In the next section we show that this had a dramatic effect on morphosyntax, as it left space for the operation of other semantic categories, whose influence on the variation increased sharply. As a result, aspect and the noun's lexical semantics at that time became two equal players in determining case variation.

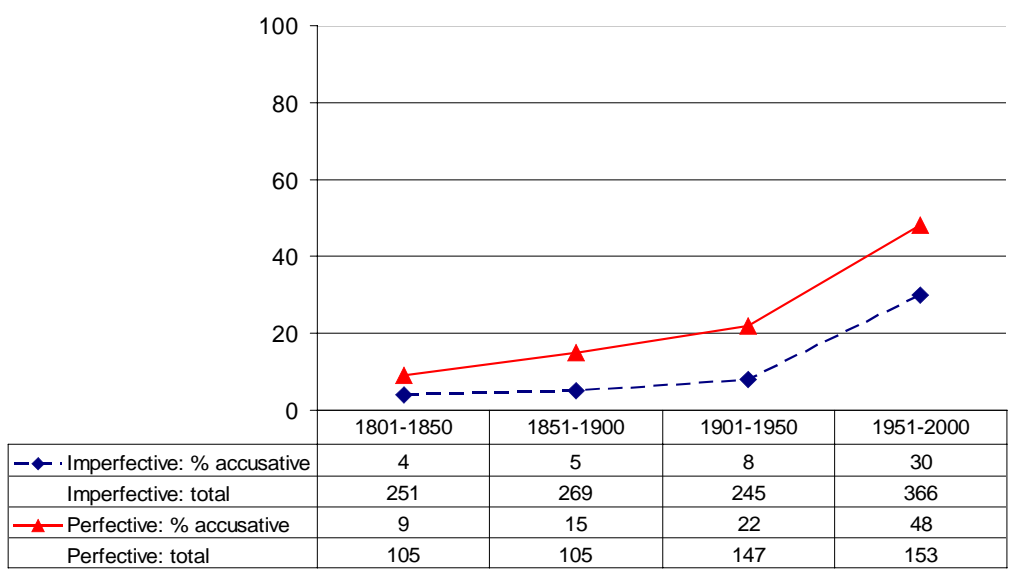

Figure 2. The role of verb aspect (finite verbs)

\section{Verb aspect and lexical semantics of the object}

As has been pointed out in previous studies on the genitive of negation in Russian (for a bibliography up to 1982 see Corbett (1986)), the case of the object is conditioned by the properties both of the governing verb and of the object. Timberlake (1986: 342) classes these two groups of conditions as event hierarchies and participant hierarchies, respectively. Conditions that fall within each of these hierarchies affect referential properties of the object, in particular, the degree of its individuation. The degree of individuation for its part accounts for case assignment preferences: the genitive is normally used with non-individuated (or less individuated) objects, while the accusative is used where there is a higher degree of individuation. Thus, animates are more individuated than inanimates, concrete nouns more than abstract, count more than non-count, and objects of perfective verbs more than those of imperfectives. Consequently the first member in each of these pairs is more likely to be in the accusative, while the second is more likely to appear in the genitive. Babby (1980) and Padučeva (2006) also discuss case assignment for direct objects from the perspective of definiteness and referentiality. Indefinite/non-referential nouns phrases are marked genitive, while definite/referential ones occur with the accusative (Babby 1980: 154-158, Padučeva 2006: 31-32; however, Padučeva points to the fact that this distribution is found only with some of speakers, while others have generalized the accusative as a default case for both types of objects). 
Relevant as the notions of referentiality, individuation and definiteness are to case assignment, in a language like Russian, which has a very limited number of means to show an NP's referential properties (thus, there are no dedicated definiteness or specificity markers), they are impractical in their raw state for use in a corpus study. Therefore, we will restrict our investigation to the contrast between concrete and abstract nouns; we know that concrete nouns are more likely to have a referential reading, and abstract nouns more likely to be used non-referentially. ${ }^{6}$ That is, the concrete/abstract distinction will serve as a practical stand-in for the related but more nebulous referential/non-referential distinction.

Data from our corpus indicate the significance of these two factors, verb aspect and concreteness/abstractness, in $19^{\text {th }}$ and $20^{\text {th }}$ century Russian. However, the relative magnitude of these factors has changed radically over time. Until the second half of the $20^{\text {th }}$ century, the effect of the semantic contrast between concrete and abstract nouns was constrained by verb aspect. Imperfective verbs strongly disfavoured the accusative, regardless of the object noun's semantics: concrete nouns governed by imperfectives take the accusative only $8 \%$ of the time in the period $1801-1850,5 \%$ in the period 1851-1900, and $9 \%$ in the first half of the $20^{\text {th }}$ century. With abstract nouns governed by imperfective verbs the accusative is attested in $2 \%, 3 \%$ and $6 \%$ of the instances respectively (Figure 3 ). Significant variation within these three periods appeared only in conjunction with perfective verbs (Figure 4): concrete nouns take the accusative $17 \%, 28 \%$ and $37 \%$ of the time in the first three periods, while abstract nouns take the accusative $2 \%, 9 \%$ and $12 \%$ of the time ${ }^{7}$.

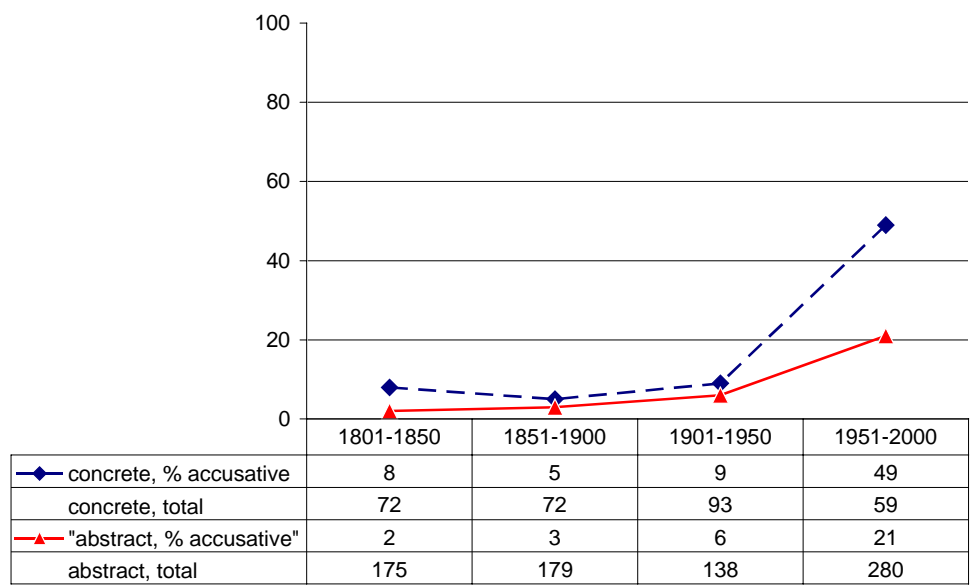

Figure 3. The role of the noun's lexical semantics with imperfective verbs

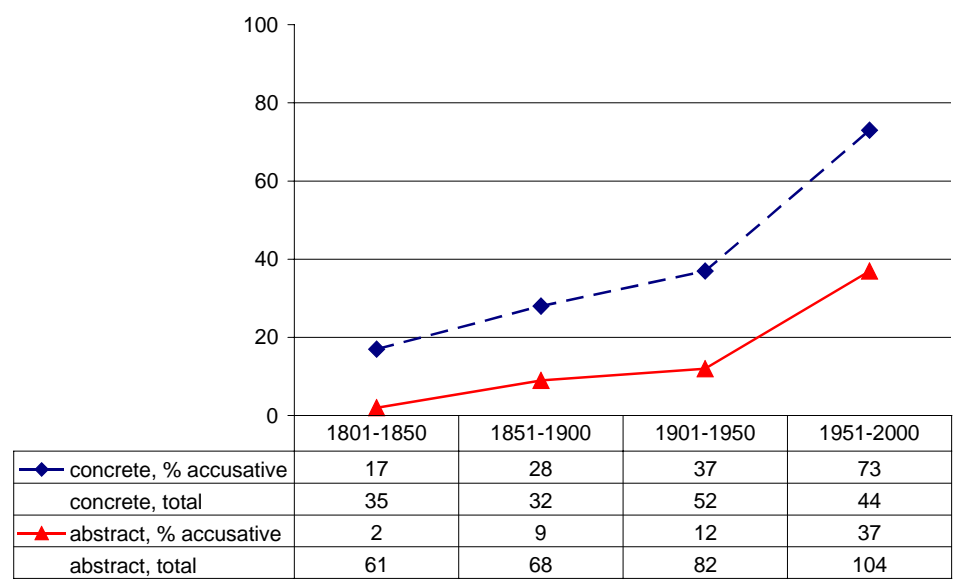

Figure 4. The role of the noun's lexical semantics with perfective verbs

In $19^{\text {th }}$ and early $20^{\text {th }}$ century Russian, verb semantics (aspect) and noun semantics (concrete/abstract) consistently play a role in object case assignment. The accusative is allowed with concrete objects and is much less favoured for abstract objects. However until the middle of the $20^{\text {th }}$ century, this split is

\footnotetext{
${ }^{6}$ It has been shown in particular that concrete nouns are located higher in the individuation hierarchy than abstracts (Hopper \& Thompson (1980: 253); Timberlake (1986: 345)). There is also a strong relationship between animacy and referentiality (see for example the Extended Animacy Hierarchy suggested by Dixon (1979: 85), which includes the referentiality hierarchy as one of its dimensions). For several reasons it would be problematic, however, to investigate the impact of referentiality on direct object case assignment in Russian using animacy distinctions. First, animates (both humans and nonhumans) have a very low frequency in the constructions in question, which would give a very small sample. Second, such a sample would include only constructions with feminine nouns, as masculine animate nouns do not overtly distinguish genitive and accusative forms. The concreteness/abstractness distinction therefore provides more tractable samples.

${ }^{7}$ To see the effect of concreteness/abstractness on case selection we have excluded instances with mass and collective nouns from these calculations. For this reason the totals in Figures 3 and 4 taken together are lower than totals in Figure 2.
} 
observed only with perfective verbs: the accusative rather frequent on concrete objects, as in (18) and (19), while abstract objects show strong preference for the genitive (20).

Concrete (animate) object

(18) Moi p'janicy ne po-ščadi-l-i by bedn-uju devušk-u. my drunkards not PFV-spare-PST-PL PARTICLE.SBJV poor-ACC.SG girl-ACC.SG 'My drunkards would have no mercy on the poor girl.' (Puškin)

Concrete (inanimate) object

(19) Ona umerla, i ja ne za-kry-l ej oč-i! she died and I not PFV-close-PST her eye-ACC.PL

'She died and I did not close her eyes.' (Bestužev)

Abstract object

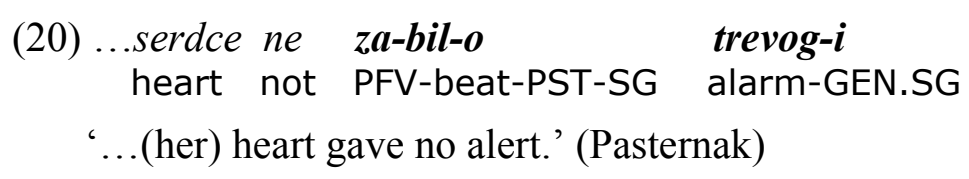

Imperfectives, on the contrary, do not allow objects to to contrast their semantic properties in the way perfectives do. That is, objects of imperfective verbs always take the genitive whether they are concrete or abstract nouns.

Concrete (animate) object
(21) ...ja li
ne ljubi-l
mo-ej
Dun-i...
... I PARTICLE not [IPFV]love-PST
my-GEN.SG Dunja-GEN.SG
‘...didn’t I really love my Dunja...?' (Puškin).

Concrete (inanimate) object
(22) Vpročem, nikto tak however nobody this.way not call-IPFV-PST this-GEN.SG greatcoat-GEN.SG
pri samom vladel'ce.
in.the.presence.of himself owner

'However, no one referred to this greatcoat as that in the presence of its owner.' (Kuprin)
Abstract object
(23) ...ja ne zaščišča-ju porok-a!
...I not defend \IPFV -PRES vice-GEN.SG
'...I do not defend vice.' (Dostoevskij)


The interdependence of the aspectual semantics of the verb and referential properties of the object has been attested in a number of unrelated languages. Thus Birkenmaier (1979:115) shows that the definiteness contrasts implicit in the choice of aspect in Russian correspond to overt definiteness in languages with articles, such as German:

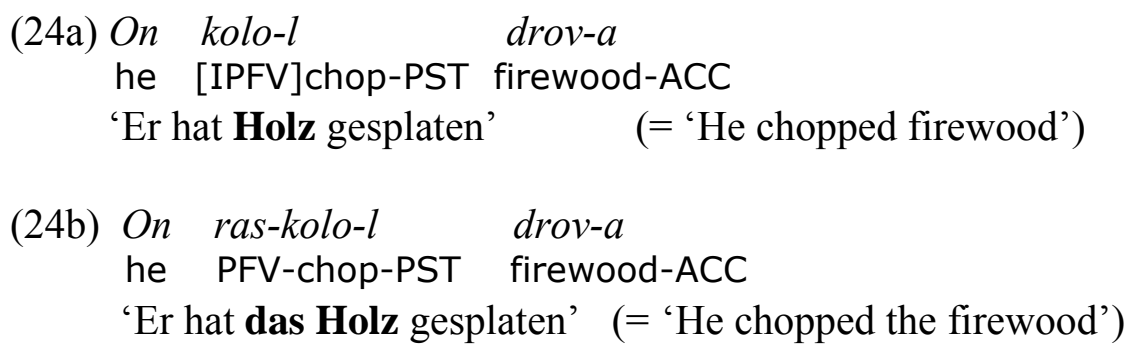

As we have shown above, $19^{\text {th }}$ and early $20^{\text {th }}$ century Russian was also sensitive to referentiality contrasts: case marking of direct objects of negated verbs varied according to whether the object was a concrete or an abstract noun. At first, this contrast was only manifested with perfective verbs, since negated imperfectives assigned the genitive case to (nearly) all objects, be they concrete or abstract. As the statistics in Figures 3 and 4 show, this state lasted until the middle of the $20^{\text {th }}$ century. In the second half of the $20^{\text {th }}$ century, the restrictions on direct object case assignment imposed by aspect were dramatically weakened, and the accusative spread with both aspects and both lexical classes. With imperfectives the frequency of the accusative increased from $9 \%$ to $49 \%$ for concrete objects and from $6 \%$ to $21 \%$ for abstracts. With perfective verbs there was an increase of $36 \%$ and $25 \%$. Hence in late $20^{\text {th }}$ century Russian genitive/accusative variation with respect to the concreteness/abstractness of the object became much less dependent on the verb's aspectual properties.

The increasing impact of the noun's lexical semantics on genitive/accusative variation in the $20^{\text {th }}$ century becomes particularly clear if we compare the two periods 1901-1950 and 1951-2000 in terms of the difference in the frequency of the accusative with concrete and abstract nouns. With imperfective verbs concrete nouns were used in the accusative only marginally more often than abstract nouns (3\% more) in the period 1901-1950, but in the period 1951-2000 concrete nouns with imperfective verbs were used with the accusative more often than abstract nouns by a margin of $28 \%$. With perfective verbs concrete and abstract nouns diverged even further: in the period 1901-1950 concrete nouns were used in the accusative more often than abstract nouns by a margin of $25 \%$, while in the period 1951-2000 the gap between concrete and abstract nouns in terms of the frequency of the accusative increased to $36 \%$. Hence the noun's lexical semantics rose in significance as a factor in determining case assignment. Correspondingly, verb aspect lost much of its significance as a determining factor in the second half of the $20^{\text {th }}$ century; compare, for example, the very close rates of change for concrete nouns with the two aspects in the $20^{\text {th }}$ century: $40 \%$ and $36 \%$.

\section{Verb aspect, noun semantics and the type of the clause}

Semantic factors conditioning case assignment are sensitive to the type of verb phrase, with infinitives much more likely to govern accusative objects than finite verbs are. Data for different periods of the $20^{\text {th }}$ century provided by different researchers indicate a clear difference in case preference with respect to the form of the governing verb. 


\begin{tabular}{|l|c|c|c|c|c|}
\hline Source & Period & $\begin{array}{c}\% \\
\text { accusative } \\
\text { governed } \\
\text { by infinitive }\end{array}$ & $\begin{array}{c}\text { Total } \\
\text { examples } \\
\text { governed } \\
\text { by infinitive }\end{array}$ & $\begin{array}{c}\% \\
\text { accusative } \\
\text { governed } \\
\text { by finite verb }\end{array}$ & $\begin{array}{c}\text { Total } \\
\text { examples } \\
\text { governed } \\
\text { by finite verb }\end{array}$ \\
\hline Restan 1960 & $1918-1959$ & 60 & 534 & 21 & 1585 \\
\hline Safarewiczowa 1960 & $1948-1955$ & 76 & 153 & 25 & 703 \\
\hline Mustajoki, Heino 1991 & $1953-1981$ & 68.5 & 890 & 27 & 1832 \\
\hline
\end{tabular}

Table 1. Frequency of the accusative with finite verbs and infinitives in 20th century Russian (according to different sources)

Data from our corpus show that the frequency of accusative objects in infinitival constructions varies according to the position of negation (directly negated infinitive as in (25), or indirect negation, as in (26)), but in any case the frequency is certainly higher than with finite governing verbs (27). This relationship, as Figure 5 indicates, holds for the whole period under investigation.

Directly negated infinitive

(25) On rešil ne pokupat' $\begin{aligned} & \text { bilet-y } \\ & \text { he decided not buy.INF } \\ & \text { ticket-ACC.PL / }\end{aligned}$
'He decided not to buy tickets'

Indirectly negated infinitive
(26) On ne xotel
pokupat'
bilet-y
/*bilet-ov
he not wanted buy.INF
ticket- ACC.PL / ticket-GEN.PL
'He did not want to buy tickets.'

Negated finite verbs
(27) On ne kupi-l bilet-y / bilet-ov
he not buy-PST ticket-ACC.PL / ticket-GEN.PL
'He did not buy tickets.'

\footnotetext{
${ }^{8}$ The figures were recalculated from Safarewiczowa's data.
} 


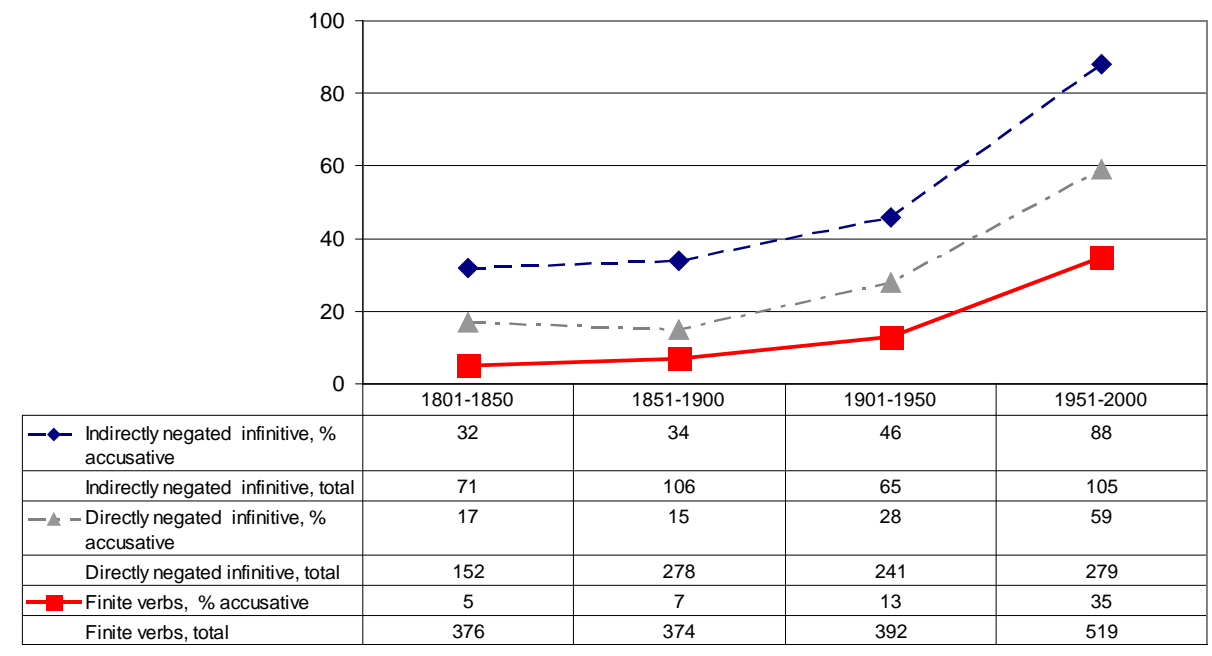

Figure 5. Frequency of the accusative with finite verbs and infinitives

In the period 1951-2000 the frequency of the accusative reached a maximum of $88 \%$ in constructions with indirect negation, i. e. the morphosyntactic change here is close to completion. In the same period accusative objects governed by finite verbs appear only $35 \%$ of the time. This is, however, the average figure and does not reflect the impact of the verb's and noun's lexical semantics. We have shown above (section 3) that if the sample with finite verbs is split further, according to perfectivity/imperfectivity and concreteness/abstractness, we arrive at significantly different frequencies of genitive/accusative use under each of the four combined conditions (perfective plus concrete, perfective plus abstract, imperfective plus concrete, imperfective plus abstract). We have also shown the relative independence of semantic factors conditioning genitive/accusative variation in the period 1951-2000: the noun's lexical semantics and verb's aspectual properties both account for the object case assignment with finite negated verbs at this time, mutually restricting each other. The question arises as to what would be the impact of semantic factors at more advanced stages of the morphosyntactic change, such as in clauses with indirect negation. Given the numerical predominance of accusative forms observed in these constructions it may be assumed that some of the factors conditioning case assignment at earlier stages have become either less significant or redundant. This could indicate that semantics, being important at any given synchronic stage (in that it shapes the competition of alternative choices within each period), is not a prime mover in diachrony; as the change progresses a number of specific semantically-based restrictions lose their significance and give way to a unified model of case assignment.

Our analysis of texts created between 1951 and 2000 has revealed dramatic differences between clauses with finite verbs and infinitives, and particularly indirectly negated infinitives, as in (11). This is due to differences in the semantic conditioning factors in the two clause types. Thus, as the statistics in Table 2 show, the aspect of a governing infinitive does not have any significant influence on object case assignment with indirectly negated infinitives. ${ }^{9}$ The percentages indicate that indirectly negated infinitives are close to generalizing the accusative, as aspect is no longer a factor. Restrictions, however, are imposed by the noun's lexical semantics, which constrains the spread of the innovation (Table 3). ${ }^{10}$ As in clauses with finite verbs, we can observe a significant difference in case preferences

\footnotetext{
${ }^{9}$ To obtain sufficient numbers for each of the two aspects and for different lexical classes of nouns, the sample has been expanded. Hence the total number of indirectly negated infinitives in Table $2(=138)$ is higher than in Figure $5(=105)$.

${ }^{10}$ For the statistics in Table 3 mass and collective nouns are excluded, as has been done with statistics presented in Figures 3 and 4 (finite verbs). This explains why the concrete and abstract nouns in Table 3 give a total of 120, which is less than
} 
according to concreteness/abstractness. Abstract nouns used as the direct object of infinitives are generally behind concrete nouns in acquiring the accusative.

\begin{tabular}{|c|c|c|c|}
\hline \multicolumn{2}{|c|}{ imperfective } & \multicolumn{2}{c|}{ perfective } \\
\hline$\%$ accusative & total & $\%$ accusative & total \\
\hline 81 & 76 & 76 & 62 \\
\hline
\end{tabular}

Table 2 . The use of the accusative with indirectly negated infinitives (1951-2000)

\begin{tabular}{|c|c|c|c|}
\hline \multicolumn{2}{|c|}{ concrete nouns } & \multicolumn{2}{c|}{ abstract nouns } \\
\hline$\%$ accusative & total & $\%$ accusative & total \\
\hline 93 & 44 & 74 & 76 \\
\hline
\end{tabular}

Table 3. Abstract and concrete accusative objects with indirectly negated infinitives (1951-2000)

\section{Conclusions}

The history of the Russian genitive of negation reveals that there may be a subtle switch in the (relative weight of) semantic factors involved in case assignment, showing that we cannot treat all instances of case assignment as reducible to one predictive semantic factor. The analysis of variation according to several conditioning factors within four time periods has shown that, as the innovative form expands, choices become more semantically specific. On the other hand, the fact that similar morphosyntactic choices are motivated by different semantic factors, if we contrast different periods, clearly indicates that these factors conditioning synchronic variation in case assignment are ephemeral from a diachronic perspective: they emerge as the change starts and have a role so long as there is a choice of case. They may be restricted or ousted by other factors, or even replaced by a general rule that eliminates variation altogether. Thus, the lexical semantics of the object noun is much more important for genitive/accusative variation now than it had been before the middle of the $20^{\text {th }}$ century, while the role of aspectual semantics, which had been a dominating factor in previous periods, has now been diminished under some syntactic conditions (with finite verbs) or reduced to insignificance under others (with indirectly negated infinitives). On the one hand, the direction of change remains constant, while on the other, some contributing factors become more prominent in the course of time, and some gradually decline in influence.

\section{References}

Abraham, Werner (1997). The interdependence of case, aspect and referentiality in the history of German: the case of the verbal genitive. In: Ans van Kemenade \& Nigel Vincent (eds.), Parameters of Morphosyntactic Change, Cambridge: Cambridge University Press. 29-61.

Babby, Leonard H. (1980). Existential sentences and negation in Russian (Linguistica Extranea:

Studia, 8). Ann Arbor: Karoma.

Bailyn, John F. (1997) Genitive of negation is obligatory. In: W. Browne, E. Dornsich, N. Kondrashova \& D. Zec (eds). Annual Workshop on Formal Approaches to Slavic Linguistics: The Cornell Meeting 1995, Ann Arbor: Michigan Slavic Publications. 84-114.

Birkenmaier, Willy (1979). Artikelfunktionen in einer artilkellosen Sprache, München: Wilhelm Fink Verlag.

Borkovskij V. I. (1978). Istoričeskaja grammatika russkogo jazyka: sintaksis. Prostoe predloženie. Moscow: Nauka.

Bulaxovskij, L. A. (1954). Russkij literaturnyj jazyk 1-j poloviny XIX v. Moscow.

the total number of indirectly negated infinitives in Table 2 . 
Comrie, Bernard (1976). Aspect. Cambridge: Cambridge University Press.

Corbett, Greville G. (1986). The use of the Genitive or Accusative for the Direct Object of Negated Verbs in Russian: A Bibliography, In: Richard D. Brecht \& James S. Levine. (eds), Case in Slavic. Columbus: Slavica Publishers. 361-372.

Dixon, R. M. W. (1979). Ergativity. Language 55 (1).59-138.

Dončeva, Ljudmila. (1962). Njakoi sposobi na izrazjavane kategorijata opredelenost/neopredelenost v ruskite otricatelni izrečenija v sravnitelen plan s bălgarski ezik, Ezik i literatura, 17, No 2, 25-40.

Hopper, Paul \& Sandra Thompson. (1980). Transitivity in grammar and discourse. Language, 56 (2).251-299.

Kiparsky, Paul (1998). Partitive Case and Aspect. In: Miriam Butt \& Wilhelm Geuder (eds), The Projection of Arguments: Lexical and Compositional Factors. Stanford: CSLI Publications. 265-307.

Kroch, Anthony (1989). Reflexes of grammar in patterns of language change. Language Variation and Change 1.199-244.

Leiss, Elizabeth. (1992). Die Verbalkategorien des Deutschen. [Studia Slavica Germanica 31.] Berlin: De Gruyter.

Mustajoki, Arto \& Hannes Heino (1991). Case Selection for the Direct Object in Russian Negative Clauses. (Slavica Helsingiensia 9). Helsinki: Helsinki University Press.

Padučeva, E. V. (2006). Genitiv dopolnenija v otricatel'nom predloženii. Voprosy jazykoznanija 6.21-43.

Partee, Barbara \& Vladimir Borschev (2002). Genitive of negation and scope of negation in Russian existential sentences. In: Jindřich Toman (ed). Annual Workshop on Formal Approaches to Slavic Linguistics: the Second Ann Arbor Meeting 2001 (FASL 10). Ann Arbor: Michigan Slavic Publications. 181-210.

Restan, Per (1960). The objective case in negative clauses in Russian: the genitive or the accusative? Scando-Slavica 6. 92-112.

Safarewiczowa, Halina (1960). Forma dopołnenia bliższego w rosyjskym zdaniu zaprzeczonym, część II. Slavia Orientalis 9, pt 1. 69-137.

Švedova N. Ju. (ed). (1980). Russkaja grammatika. Moscow: Nauka.

Taubenberg, L. I. (1958). Sistema glagol'nogo i imennogo upravlenija v russkom jazyke konca XVIInačala XVIII vv. Riga.

Timberlake, Alan (1986). Hierarchies in the genitive of negation. In: Richard D. Brecht \& James S. Levine. (eds), Case in Slavic. Columbus: Slavica Publishers. 338-360.

Tomson A. I. (1903). Vinitel'nyj padež prjamogo dopolnenija v otricatel'nyx predloženijax v russkom jazyke. Russkij filologičeskij vestnik 49. 192-234. 